\title{
PENGEMBANGAN MEDIA PEMBELAJARAN TEMA PANAS DAN PERPINDAHANNYA BERBASIS MULTIMEDIA SISWA KELAS V SEKOLAH DASAR
}

\author{
Andi Haslina \\ Universitas Mulawarman \\ andihaslina74@gmail.com
}

\begin{abstract}
ABSTRAK
Penelitian ini bertujuan (1) untuk mengetahui langkah - langkah pengembangan media pembelajaran tema panas dan perpindahannya berbasis multimedia bagi siswa kelas V Sekolah Dasar, (2) untuk mengetahui kelayakan pengembangan media pembelajaran tema panas dan perpindahannya berbasis multimedia bagi siswa kelas V Sekolah Dasar, (3) untuk mengetahui keefektifan pengembangan media pembelajaran dalam tema penas dan perpindahannya berbasis multimedia. Metode yang digunakan dalam penelitian ini adalah metode penelitian dan pengembangan atau R\&D (Research and Development). Dari penelitian ini dapat disimpulkan bahwa pengembangan media pembelajaran tema panas dan perpindahannya berbasis multimedia siswa kelas V Sekolah Dasar dikembangkan berdasarkan model pengembangan menurut Borg dan Gall. Dalam implementasinya penelitian ini hanya menggunakan sampai pada langkah pengembangan ke tujuh (7), dan dikembangkan sesuai prinsip instruksional yaitu (1) analisis kebutuhan, (2) desain dan pengembangan produk, (3) validasi produk I, (4) uji kelompok kecil, (5) validasi produk II, (6) uji kelompok besar, dan terakhir (7) evaluasi dan desiminasi. Hasil validasi dari validator tahap II yaitu ahli materi dan ahli media sebesar $89 \%$ dan $87 \%$ dengan kategori sangat layak. Setelah dilakukan evaluasi disimpulkan bahwa terdapat perbedaan sebesar 35\% setelah menggunakan media pmebelajaran tersebut sehingga media pembelajaran ini layak untuk digunakan dalam proses pembelajaran
\end{abstract}

Kata kunci: pengembangan media pembelajaran, multimedia, panas dan perpindahannya

\begin{abstract}
This research aims (1) to find out the steps of developing hot theme learning media and multimedia-based displacement for elementary school $V$ students, (2) to find out the feasibility of developing hot theme learning media and its multimediabased displacement for elementary school V students, (3) to know the effectiveness of learning media development in the theme of pens and multimedia-based displacement. The methods used in this study are research and development methods or R\&D (Research and Development). From this research can be concluded that the development of hot theme learning media and its multimedia-based displacement of grade $V$ elementary school students was developed based on the development model according to Borg and Gall. In its implementation this research only uses up to the seventh development step (7), and was developed in accordance with instructional principles namely (1) needs analysis, (2) product design and development, (3) product validation I, (4) small group test, (5) product validation II, (6) large group test, and last (7) evaluation and denomination. The validation results from phase II validators are material experts and media experts by $89 \%$ and $87 \%$ with very viable categories. After the evaluation it was concluded that there was a difference of $35 \%$ after using the learning media so that this learning medium is worth using in the learning process
\end{abstract}

Keywords: development of learning media, multimedia, heat and displacement

\section{PENDAHULUAN}

Kegiatan pendidikan, teknologi pendidikan dan media pendidikan pada saat ini sangat membutuhkan pemanfaatan teknologi komunikasi untuk meunjang kegiatan belajar mengajar.

Kegiatan pendidikan erat kaitannya denga kegiatan pembelajaran. Menyampaikan suatu pesan dari sumber berita atau secara langsung ataupun menggunakan media yang dugunakan kepeda penerima pesan yang mana merupakan dasar dari kegiatan pembelajaran. Sumber pesan utama dalam kegiatan pembelajaran adalah guru, pesan yang disampaikan adalah materi pembelajaran, alat bantu yang digunakan untuk mengirim isi pesan adalah media, dan siswalah penerima pesan.

Sekolah dan guru sendiri memiliki peran dalam pembelajaran. Sekolah berperan sebagai institusi yang melahirkan kebijakan, 
dan guru berperan sebagai aktor utama di lapangan (kelas). Faktor yang berpengaruh besar dalam keberhasilan pembelajaran yaitu dari cara guru mengajar serta media yang digunakan oleh guru tersebut.

Berdasarkan tulisan di atas maka dapat dikatakan bahwa kemajuan Ilmu pengetahuan, teknologi, dan pemanfaatan media pembelajaran dalam kegiatan pembelajaran akan memberikan dampak yang besar di dalam keberhasilan kegiatan pembelajaran. Kemajuan Ilmu pengetahuan dan teknologi (IPTEK) juga menyediakan berbagai macam media pembelajaran yang semula terbatas macamnya dan bersifat konvensional menjadi media pembelajaran berbasis teknologi dan informasi baik bersifat online maupun offline yang dapat membantu guru menyampaikan materi pelajaran kepada siswa dan mempermudah siswa dalam melalukan akses materi serta pengulangan pembelajaran secara mandiri yang dapat mengatasi keterbatasan waktu pembelajaran di sekolah.

Setelah melakukan obeservasi lapangan di SD Negeri 003 Anggana masih jarang guru yang menggunakan media pembelajaran berbasis multimedia di sekolah tersebut dan hanya mengguankan system mengajar konvensional selain itu belum pernah dilakukan penelitian yang serupa di sekolah tersebut.

Berdasarkan uraian permasalahan tersebut rumusan masalah dari penelitian pengembangan ini adalah bagaimana langkah-langkah pengembangan media pembelajaran berbasis multimedia dalam tema panas dan perpindahannya bagi siswa kelas v sekolah dasar, bagaimana kelayakan desain pengembangan media pembelajaran berbasis multimedia dalam tema panas dan perpindahannya bagis siswa kelas $\mathrm{v}$ sekolah dasar, dan bagaimana keefktifan desain media pembelajran berbasis multimedia dalam tema panas dan perpindahannya bagi siswa kelas $\mathrm{v}$ sekolah dasar.
Sesuai dengan rumusan masalah, tujuan penelitian pengembangan ini yaitu untuk mengetahui langka-langkah pengembangan media pembelajaran berbasis multimedia dalam tema panas dan perpindahannya bagi siswa kellas $\mathrm{v}$ sekolah dasar, untuk mengetahui kelayakan pengembangan media pembelajaran berbasis multimedia dalam tema panas dan perpindahannya bagi siswa kelas $\mathrm{v}$ sekolah dasa, dan untuk mengetahui keefektifan pengembangan media pembelajran berbasis meultimedia dalam tema panas dan perpindhannya siswa kelas $\mathrm{v}$ sekolah dasar.

\section{METODE PENELITIAN}

Penelitian ini merupakan jenis penelitian dan pengembangan Research and Development (R\&D) dengan model Borg and Gall. Dari sepulu langkah yang dikembangkan oleh borg and Gall, pada peneitian ini implementasinya dibuat dan diringkas menjadi tujuh (7) tahap. Hal ini diakrenakan keterbatasan, baik dari segi waktu maupun biaya. Tujuh tahap pengembangan tersebut yaitu (1) analisis kebutuhan, (2) tahap desain produk awal, (3) uji coba produk tahap 1 dan revisi pertama, (4) uji coba terbatas (kelompok kecil), (5) validasi tahap kedua dan revisi, (6) tahap uji coba lapangan (kelompok besar) dan produk akhir, (7) evaluasi dan desimiansi.

\section{Tempat dan Waktu Penelitian}

Penelitian pengembangan ini dilakukan di SD Negeri 003 Anggana yang beralamat jalan Mulawarman Desa Sungai Mariam Kecamatan Anggana Kabupaten Kutai Kartanegara yang dilaksanakan pada tahun ajaran 2019/2020 pada bulan Maret 2020 pada siswa kelas lima (v).

\section{HASIL DAN PEMBAHASAN}

Penelitain pengembangan ini diawali dengan analisis kebutuhan yaitu dimulai dengan mengumpulkan data- data mengenai keadaan dan kondisi tempat penelitian 
maupun sasaran dan yang nantinya akan menggunakan hasil dari media pembelajaran ini. Hasil observasi dan studi awal nantinya akan menjadi bahan pertimbangan dalam penelitian pengembangan ini yang bertujuan untuk mengetahui proses keseluruhan dari system yang akan dikembangkan dan gambaran apa yang nantinya akan dilakukan.

Tahap selajutnya atau tahap kedua yaitu membuat desain produk awal yang terdiri dari beberapa langkah yaitu (a) pembuatan garis besar isi video pembelajaran untuk memperjelas alur dalam penelitian ini yang berisi spesifikasi yang akan dikembangkan dalam video pembelajaran yang disesuaikan mata pelajaran dengan kompetensi dasar, indikator, materi hingga tujuan pembelajran. (b) pembuatan flowchart yang merupakan alur dalam video pembelajaran mulai dari awal membuka video pembelajaran samapai sampai dengan selesai, (c) pembuatan storyboard yang berisi uraian tentang penjelasan dari masing-masing alur dalam flowchart yang berisi visualisasi dari gagasan dan aplikasi multimedia yang di buat, sehingga pembuatannya setelah flowchart selesai dibuat, (d) pengumpulan bahan-bahan berisi bahan yang diperlukan untuk melengkapi media pembelajaran yaitu materi, video, musik, gambar, foto,, dan alat-alat untuk praktek, (e) pembuatan media pembelajaran, yaitu merangkai media pembelajaran dari semua bahan yang dimulai dengan pengambilan adegan video/syuting dengan metode green screen (layar hijau) dan merekam video menggunakan kamera handphone dan Digital Singel Lens Reflex (DSLR) dengan bantuan penvahayaan lampu lighting, editing video menggunakan software corall video studio 2019 yang berfungsi melakukan seleksi pada latar hijau (green screen) dan berfungsi menggabungkan video dan penyeleksian video serta memebri efekefek transisi, animasi,pengaturan kecerahan, audio serta penambahan teks sesuai yang dibutuhkan, (f) finishing yaitupengecekan terakhir atau evaluasi untuk mengetahui titik kelamahan maupun kelebihan dari produk yang dikembangkan, dan sebagai bahan catatan untuk penulis tentang bagian mana nantinya yang harus diperbaiki kembali.

Selanjutnya dilanjutkan dengan tahap uji coba produk tahap 1 dan revisi pertama terhadap desain pengembanagan media pembelajaran. Validasi ini dilakukan oleh dua ahli, yaitu ahli materi dan ahli media, hasil dari validasi dari masing-masing validator yaitu $75 \%$ dengan kategori cukup baik atau cukup layak untuk ahli materi, sedangkan untuk ahli media yaitu 55\% dengan kategori kurang baik atau kurang layak.

Berdasarkan hasil validasi tahap 1 penulisan melakuakn revisi terhadap produk yang dikembangkan sesuai dengan saran dan kritik dari validator. Setelah produk direvisi penulis melakukan uji coba terbatas (kelompok kecil) dengn sampel sejumlah enam (6) orang yang dianggap mewakili populasi dari tiga (3) kelas siswa V SD Negeri 003 Anggana dengan hasil 71\% kategori cukup baik atau cukup layak.

Setelah mengetahui hasil dari uji kelompok kecil peneliti melakukan revisi kedua untuk mendapatkan produk ideal yang selanjutnya kembali divalidasi oleh validator ahli materi dan ahli media dengan hasil validasi kedua yaitu dari ahli materi sebesar $89 \%$ dengan kategori sangat baik atau sangat layak dan dari ahli media 86\% kategori dangat baik atau sangat layak. Hasil validasi dari validator menyatakan produk sudah layak dan siap digunakan tanpa revisi.

Selanjutnya dillakukan uji coba lapangan (kelompok besar) kepada 18 orang (responden) yaitu sampel dari tiga (3) kelas lima (v) di SD Negeri 003 Anggana yang di anggap dapat mewakili populasi secara keseluruhan, dengan hasil sebesar 89\% kategori sangat baik atau sangat layak. Dengan demikian berarti porduk media pembelajaran dpat langsung digunakan tanpa revisi lanjutan.

Tahap terakhir yaitu evaluasi dan dan desiminasi yaitu verifikasi dan validasi ulang agar produk pengembanagan yang dihasilkan layak dan dapat dipergunakan sebagai sumber belajar bagi siswa maupun untuk bahan ajar bagi guru. Tahap evaluasi penulis melakukan 
test (post test) untuk mengetahui pencapaian kognitif siswa setelah menggunakan media yang nantinya dibandingkan dengan hasil test awal atau pre test (sebelum menggunakan media). Hasil test diolah dengan cara dicari selisih nilai siswa dari sebelum menggunakan media lalu dibagi dengan jumlah siswa, hasilnya yaitu 54. Selanjutnya jumlah nilai siswa setelah menggunakan media dibagi dengan jumlah siswa meninggkat menjadi 87. Kemudia dihitung selisih nilai pre test dan post test hasilnya 35.

Setelah mengetahui bahwa media pembelajaran tersebut layak, penulis melakuakn desiminasi dengan mendistribusikan produk media pembelajaran tersebut kepada seluruh anggota Kelompok Kerja Guru (KKG) Kecamatan Anggana, khususnya guru kelas lima (V) dalam bentuk Compact Disk (CD).

\section{PENUTUP}

Berdasarkan hasil penelitian ini dapat disimpulkan bahwa penelitian pengembangan ini adalah pengembangan media pembelajaran tema panas dan perpindahannya berbasis multimedia siswa kelas $\mathrm{v}$ sekolah dasar menggunakan model pengembangan Borg and Gall yang bertujuan untuk mengembangankan dan memvalidasi produk yang digunakan dalam pendidika. Langkahlangkah penelitian yang digunakan pada penelitian ini telah disederhanakan menjadi tujuh langkah dari sepuluh langkah yang dikembangkan dalam model Borg and Gall.

Tujuh langkah yang digunakan yaitu (1) analisis kebutuhan, (2) desai produk awal dan pengembangan produk, (3) validasi produk tahap I (validasi dilakukan oleh validator), (4) uji kelompok kecil (uji coba terbatas), (5) validasi produk tahap II (validasi oleh validator), (6) uji kelompok besar (uji coba lapangan), (7) evaluasi .

Berdasarkan peenlitian yang telah dilakukan dapat disimpulkan bahwa terdapat perbedaan pada siswa sebelum dan sesudah menggunakan media pembelajaran tersebut. Perbedaan ini berdampak pada kelayakan media pembelajaran tersebut yang dilakukan dengan membandingkan hasil pre test dan post test siswa yang diketahui hasilnya mengalami peningakatan sebesar 35\%. Berdasarkan peningkatan hasil belajar siswa tersebut, dapat disimpulkan bahwa media pembelajaran ini layak digunakan dan dapat meningkatkan hasil belajar siswa.

\section{DAFTAR PUSTAKA}

Arief S. Sadiman, dkk. 2003. Media Pendidikan Pengertian, Pengembanagan, dan pemanfaatannya. Jakarta: Raja Grafindo Persada

Arsyad, Azhar. 2015. Media Pembelajaran. Jakarta: Raja Grafindo

Darmawan, Deni. 2012. Teknologi Pembelajaran. Bandung: Remaja Rosdakarya

Daryanto. 2011. Media Pembelajran. Yogyakarta: Gave Media

Emzir, 2013. Metodologi Penelitian Pendidikan. Depok: PT. Raja Grafindo Persada

Kustandi, dkk. 2011. Media Pembelajaran; Manual dan Digital. Bogor: Ghalia Indonesia

Munir. 2012. Multimedia, Konsep \& Aplikasi dalam Pendidikan. Bandung: Alfabeta

Sugiyono. 2011. Metode Penelitian Kuantitatif dan $R \& D$. Bandung: Alafbeta

Sugiono, 2015. Metode Penelitian \& Pengembangan Research and Development. Bandung: Alfabeta 